\title{
ANALYSIS OF THE LEMMA MATEŘSTVÍ (MOTHERHOOD)
}

\author{
ZUZANA ČERNÁ ${ }^{1}-$ RADEK ČECH $^{2}$ \\ ${ }^{1,2}$ Faculty of Arts, University of Ostrava, Czech Republic
}

ČERNÁ, Zuzana - ČECH, Radek: Analysis of the lemma Mateřství (Motherhood). Journal of Linguistics, 2019, Vol. 70, No 2, pp. $244-253$.

\begin{abstract}
The paper presents results of analysis of the lemma mateřstvi 'motherhood'. The authors applied methods of corpus linguistics and discourse analysis - the corpus assisted discourse studies approach - in order to survey representations of the lemma in Czech journalistic texts published from 2010 to 2014, sorted the results into discourse categories on the basis of collocation and concordance analysis, and found out that chief referential discourse-of-motherhood categories were surrogate motherhood, relationship of motherhood and career, delight from motherhood, family relationships, financial and time aspects of motherhood, changes brought by motherhood, and active motherhood. Surrogate motherhood was presented as a solution to women who cannot have a baby themselves, nevertheless also as a complicated issue, in which case emphasis was put on relevant legislation. Motherhood was presented as a danger for a woman's career, however also as a source of joy, an essential relationship within a family, a right for financial support from the state, a life change, an activity, and an entity closely connected to time factors.
\end{abstract}

Keywords: motherhood, discourse, mass media, corpus, CADS

\section{INTRODUCTION}

Motherhood is specific - each of us has a mother, some of us are mothers, motherhood has been discussed in various spheres of humanities (cf. family psychology, family sociology) or pictured in multiple works of art (randomly Whistler's Arrangement in Grey and Black No. 1, Michelangelo's sculptural group Madonna, Dvořák's Stabat Mater).

Models of motherhood have changed in Czech society in recent decades. What was a dominant norm, i.e. mother taking care both of children and work and father going to work, but not much involved in the daily care of children, is not viewed as the only model any more. Women endeavor to have both children and a job, men participate in the care of their children and sometimes stay on parental leave, families lead dual-career lives and employers offer flexible working hours and part-time jobs to help parents balance work and life. On the other hand, there is a growing number of couples who decide to postpone starting a family or not to have it at all, birth-rate is insufficient and new forms of expecting a child (artificial insemination or surrogate motherhood) have appeared. 
We inquired how the phenomenon of motherhood was reflected in Czech journalistic texts, which are generally considered to be a powerful tool to influence public opinion. In order to survey what leading issues related to motherhood they present and what discourse of motherhood they produce, we implemented the corpus assisted discourse studies approach (CADS), being inspired mainly by Baker [1] and [2]. We surveyed representations of the lemma materstvi 'motherhood' in a corpus of journalistic texts available in the Czech Corpus of Contemporary Written Czech SYN2015 [3]; we observed the frequency of the lemma with regard to a medium, journal title, text type and genre, made its collocation analysis, and classified the collocates into discourse categories; we searched for repeated discourse patterns that the lemma appeared in by means of concordance analysis and attempted to interpret them.

The research submitted is a partial probe within a broader project aimed at surveying Czech mass media discourse of motherhood. Analysis of lemmas such as rodičovství 'parenthood', těhotenství 'pregnancy' or porod 'childbirth', which emerged from the research by way of neural networks (Kubát, Hůla [4]) as close to the lemma matersství (motherhood), as well as analyses of data from older and spoken corpora, will follow.

\section{THEORETICAL BACKGROUND}

The term discourse has been widely used in humanities, however with various meanings: for example, Stubbs [5] defines it as a language above a sentence or clause, Fairclough [6] as an element of social life which is closely interconnected with other elements and effects power relations in the society, Blommaert [7] as a language in action which forms objects and produces a particular version of events. Baker [1] understands it as a practice which systematically forms objects of which it speaks; there are many discourses, each with a different story to tell about the world. We follow mainly Blommaert's and Baker's concept in the paper.

Discourse of motherhood has been studied with various aims, from multiple perspectives and by way of various methods and techniques. Feminism, which states that mothers are oppressed and constrained to home environment and care for family members by dominant patriarchal discourses of motherhood and ideal womanhood (Buchanan [8], Rich, McClatchy [9], Vincent [10] and others) and that women are stressed due to the discrepancy between those discourses and their own view of motherhood and womanhood (Haratyan [11], Butler [12], Parker [13], and others), belongs to the most influential research-on-motherhood streams.

Considering the discourse of motherhood in media, e.g. Woodward [14] and Tomešová [15] are worth mentioning: Woodward searched the emergence of a figure of New Mother, independent and paid for her work, in women's magazines; Tomešová found out that the image of a pregnant woman is constructed solely from the perspective of maternity, ignoring others components of her life such as sex or job. 
This paper of ours aims at surveying the issue of motherhood presentation in Czech journalistic texts. Unlike the aforementioned researchers, we made use of a corpus-driven approach to discourse in order to describe how motherhood is treated in the corpus used.

\section{METHODOLOGY AND MATERIAL}

We made use of the qualitative-quantitative strategy of the CADS, considering - in compliance with Baker [2] - both parts equal. Corpus linguistics helps researchers minimize the interpretation bias and make use of large real life data sets; discourse analysis enables them interpret what is beyond the numbers.

First, we surveyed the frequency of the lemma materstvi 'motherhood' from different aspects (medium; journal title; text type; genre) and made its collocation analysis by means of the T-score association measure. We decided on the T-score with regard to the fact that we were looking for typical collocations of the lemma and, according to Brezina [16], T-score is highly suitable for detection of frequent non-exclusive collocations.

We set the collocation span L5-P5 (i.e. 5 positions to the left, 5 to the right) from the KWIC (key word in context), the minimum frequency of a collocate in the subcorpus at 3 and the minimum frequency of a collocate in context also at 3 .

We treated autosemantic collocates only in our follow-up analysis. We determined the main discourse categories on the basis of the T-score results and on the contextual meaning of individual collocates. This step was implemented manually. Subsequently, by way of concordance analysis, we searched for repeated discourse patterns that motherhood appeared in.

As mentioned above, we analyzed journalistic texts from the Czech Corpus of Contemporary Written Czech SYN2015 [3], namely the text group NMG: journalism (NMG: publicistika) of approximately 33 mil. tokens published between 2010 and 2014. It consists of NEW: traditional journalism (NEW: tradiční publicistika) and LEI: leisure time journalism (LEI: volnočasová publicistika). We made use of the KonText application.

\section{RESULTS}

The lemma materstvi 'motherhood' appeared 236 times in the aforementioned subcorpus, with the value of instances per million words (hereinafter i. p. m.) of 5.94, which indicates that motherhood was not a moving topic (lemmas with this frequency have a rank laying in the interval $r=<11086 ; 11126>$ in rank-frequency distribution of lemmas in SYN2015, the corpus contains 363819 individual lemmas). 
Compared with the NFC: oborová literatura (NFC: expert literature; 5.89 i. p. m.) and FIC: beletrie (FIC: fiction; 3.63 i. p. m.) subcorpora, the i. p. m. was not considerably higher in NMG: publicistika (NMG: journalism; 5.94 i. p. m.).

The average reduced frequency (hereinafter ARF) of the lemma materstvi 'motherhood' in the NMG subcorpus was 52.26, indicating that the lemma was distributed slightly unevenly. According to Křen and Cvrček [3], the value of ARF for a certain expression is its corrected frequency, based on the distribution of its occurrence in a corpus: the closer the ARF is to frequency, the more even the distribution is; expressions that occur in a single cluster within a corpus, reach the ARF value of 1 .

We found out that the lemma was more than twice as frequent in magazines (5.85 i. p. m.) as in newspapers (2.77 i. p. m.). In compliance with our expectations, the lemma occurred most frequently in the genre of lifestyle (29.38 i. p. m.), social life (13.57 i. p. m.), and society (10.25 i. p. m.). It appeared mostly in women's magazines - the highest i. p. m. of 148.15 being in Maminka (Mummy), which was not surprising. The i. p. m. in newspapers ranked towards the end of the imaginary ladder (Hospodářské noviny 1.7 i. p. m., Mladá fronta Dnes 1.35 i. p. m.); for details, see Table 1.

\begin{tabular}{|r|l|r|}
\hline & Journal title & i. p. $\mathbf{~ . ~}$ \\
\hline 1 & Maminka (Mummy) & 148.15 \\
\hline 2 & Marie Claire & 72.49 \\
\hline 3 & Playboy & 55.52 \\
\hline 4 & Rytmus života (Life Rhythm) & 55.19 \\
\hline 5 & Svět ženy (A Woman's World) & 54.41 \\
\hline 6 & Esprit & 53.21 \\
\hline 7 & Ona dnes (Her Today) & 48.24 \\
\hline 8 & Žena a život (Woman and Life) & 39.13 \\
\hline 9 & Story & 32.13 \\
\hline 10 & Katka (Kate) & 32.12 \\
\hline 11 & Elle & 30.91 \\
\hline & $\ldots$ & 9.39 \\
\hline 54 & Hospodářské noviny (Economic News) & 1.70 \\
\hline 55 & Mladá fronta Dnes (Young Frontline Today) & 1.35 \\
\hline & $\ldots$ & 0.50 \\
\hline 58 & Sport & \\
\hline
\end{tabular}

Tab. 1. Frequency of the lemma materstvi in individual title 
These numbers might result from the fact that the issue of motherhood is naturally closer to women, especially to mothers, than men and that there is an absence of stimulating issues related to motherhood which newspapers could be interested in.

Based on T-score, the lemma made strong collocations with autosemantic lemmas presented in Table 2. It is remarkable that the first 16 autosemantic collocates covered $50 \%$ of all autosemantic tokens modified by mateřstvi 'motherhood'.

\begin{tabular}{|r|l|r|r|l|r|}
\hline & Lemma & T-score & & Lemma & T-score \\
\hline 1 & náhradní (surrogate) & 4.90 & 34 & plodnost (fertility) & 1.73 \\
\hline 2 & žena (woman) & 4.44 & 35 & porodit (deliver) & 1.73 \\
\hline 3 & kariéra (career) & 4.24 & 36 & odkládat (postpone) & 1.73 \\
\hline 4 & užívat (enjoy $\left.{ }^{1}\right)$ & 3.60 & 37 & legální (legal) & 1.73 \\
\hline 5 & dítě (child) & 3.26 & 38 & upravovat (treat) & 1.73 \\
\hline 6 & matka (mother) & 3.14 & 39 & zvládat (manage) & 1.73 \\
\hline 7 & život (life) & 3.10 & 40 & upozorňovat (warn) & 1.73 \\
\hline 8 & peněžitý (financial) & 3.00 & 41 & užít (enjoy ${ }^{2}$ ) & 1.73 \\
\hline 9 & pomoc (help) & 2.81 & 42 & mateřský (maternal) & 1.73 \\
\hline 10 & změnit (change) & 2.63 & 43 & zkrátka (simply) & 1.72 \\
\hline 11 & hodně (a lot) & 2.55 & 44 & přinášet (bring) & 1.72 \\
\hline 12 & velký (big) & 2.51 & 45 & povinnost (duty) & 1.72 \\
\hline 13 & role (role) & 2.43 & 46 & skvělý (great) & 1.72 \\
\hline 14 & ted' (now) & 2.38 & 47 & tradiční (traditional) & 1.72 \\
\hline 15 & nárok (right) & 2.23 & 48 & Česko (Czechia) & 1.71 \\
\hline 16 & aktivní (active) & 2.23 & 49 & řešit (solve) & 1.71 \\
\hline 17 & spojený (connected) & 2.22 & 50 & manžel (husband) & 1.71 \\
\hline 18 & práce (job) & 2.17 & 51 & láska (love) & 1.71 \\
\hline 19 & doba (period) & 2.14 & 52 & rozhodnout (decide) & 1.69 \\
\hline 20 & hnutí (movement) & 1.99 & 53 & nyní (now) & 1.69 \\
\hline 21 & pozdní (late) & 1.99 & 54 & rodina (family) & 1.69 \\
\hline 22 & radost (joy) & 55 & snažit (strive) & 1.68 \\
\hline 23 & téma (topic) & 56 & mluvit (speak) & 1.65 \\
\hline 24 & zákon (law) & 57 & poslední (last) & 1.65 \\
\hline 25 & pracovat (work) & 58 & muž (man) & \\
\hline & & & & & \\
\hline
\end{tabular}

${ }^{1}$ Imperfectum.

${ }^{2}$ Perfectum. 


\begin{tabular}{|r|l|r|r|l|r|}
\hline & Temma & T-score & & Lemma & T-score \\
\hline 26 & věc (thing) & 1.94 & 59 & čas (time) & 1.65 \\
\hline 27 & rok (year) & 1.92 & 60 & začít (begin) & 1.62 \\
\hline 28 & myslet (think) & 1.92 & 61 & druhý (second) & 1.61 \\
\hline 29 & český (Czech) & 1.89 & 62 & jiný (other) & 1.59 \\
\hline 30 & dobrý (good) & 1.73 & 64 & dva (two) & 1.58 \\
\hline 31 & surogátní (substitutive) & 1.73 & 65 & jít (go) & 1.57 \\
\hline 32 & odsouvání (postponing) & 1.73 & & & 1.55 \\
\hline 33 & skloubit (harmonize) & & & & \\
\hline
\end{tabular}

Tab. 2. Autosemantic collocates to the lemma mateřstvi

In compliance with Baker [1] and [2], we conducted a discourse analysis, determining the chief discourse-of-motherhood categories on the basis of the aforementioned T-score results and the contextual rather than the dictionary meaning of individual collocates (see Table 3). This step was implemented manually and its results are therefore subject to the researchers' decision.

\begin{tabular}{|l|l|}
\hline Discourse category & Representing lemmas \\
\hline surrogacy & surrogate, law, Czechia, legal, treat \\
\hline career & career, woman, job, work, harmonize, manage \\
\hline joy & joy, enjoy \\
\hline family relations & child, mother, life, role, husband, family, love, man \\
\hline finances & financial, help, right \\
\hline changes & change \\
\hline activity & active, movement \\
\hline time & period, late, year, postponing, delaying, now, last, time \\
\hline
\end{tabular}

Tab. 3. Discourse-of-motherhood categories

Through a follow-up manual analysis of all concordance lines, we found out what emerged from the discourse categories:

Surrogacy: Motherhood and surrogacy are closely related; their collocation was the strongest one of all that emerged on the basis of T-score. Náhradni' 'surrogate' was never used with anything else than materstvi' 'motherhood'. The discourse of surrogacy was concentrated mainly round the collocates náhradni 'surrogate', zákon 'law', Česko 'Czechia', legální 'legal', upravovat 'treat' - it discussed mostly the legality / illegality of surrogacy in the Czech Republic, or in other countries. Surrogacy is perceived as a help to women who cannot have a baby themselves: Náhradní matka se nechá oplodnit spermatem muže, pokud je jeho žena neplodná. 
('A surrogate mother undergoes artificial insemination when an ovum of a woman who cannot have a baby herself is placed into her womb.') What is viewed as problematic is the immoral business with surrogacy and the unclear status of the biological and the "target" mother because komplikace mohou nastat, když se náhradni matka po porodu dítěte nevzdá. Podle zákona je totiž matkou žena, která dítě porodí, nikoli dárkyně vajička! ('complications may turn up when a surrogate mother does not hand over the child. In compliance with the Act, mother is a woman who gives birth, not the donor of the ovum!')

Career: This discourse category was formed mainly round the collocates kariéra 'career', žena 'woman', práce 'job', pracovat 'work', skloubit 'harmonize', and zvládat 'manage' and it states that motherhood endangers a woman's career and women are to make a pro- motherhood/pro-career choice, others postpone motherhood to later life periods, and others somehow try to balance both. Mothers experience discrimination in the labour market because muži se méně starají o domácnost a děti. Ženy kvi̊li mateřství odsunuji kariéru, nevezmou náročnější, tudiž lépe placenou, pozici. ('men take care of household and children less. Women postpone their career because of motherhood, they do not take a more demanding, therefore a better paid, job.') The category of time could be well included in this category because time was often referred to in connection with postponed motherhood but as it fits into the category of time as well, we decided to discuss it there.

$\underline{\text { Joy: }}$ : Motherhood was perceived as delight in women-mothers, judging from the frequently used expressions radost 'joy' and uživat, užit 'enjoy'. The collocation uživat / užit si mateřství 'enjoy motherhood' appeared 15 times, joy made collocations with motherhood only 4 times (out of which 3 times it went together with tiha / strast / povinnost mateřstvi - 'burden / duties of motherhood'). The collocate skvělý 'great' could also be included in this category as it expresses a high degree of pleasure related to motherhood.

Family relations: Motherhood is set into a context of family relations; this discourse category was formed chiefly round the collocates ditè 'child', matka 'mother', život 'life', role 'role', manžel 'husband', rodina 'family', láska 'love', manželé 'husband / man and wife's), that is those generally considered typical for nuclear family positions, roles and relationships. Motherhood is presented as a significant component (directly a role) of a woman's life, of the relationships within a family and of a family as a whole. Although surrogacy and employment of women-mothers might also be included in this category, they were already discussed above and are therefore omitted here.

Finances: This discourse category was formed chiefly round the collocates peněžity' 'financial', pomoc 'help', and nárok 'right'. It implies that motherhood is

${ }^{3}$ Czech manžel corresponds with English husband, manželé with man and wife. With the collocate manžel, both meanings are included. 
financially demanding and the financial help provided to mothers by the state to partially counterbalance their lower income, is their right. Podminkou toho, aby žena mohla pobirat peněžitou pomoc v mateřství, je, že nesmi mit žádný jiný př́jem. ('To be granted a motherhood benefit, women must not have any other income.') Motherhood gives women a right to help: Ano, máte nárok na peněžitou pomoc v mateřství. ('Yes, you have a right to financial help in motherhood.') It was interesting that the collocate pomoc 'help' was related to the financial aspect of motherhood only.

Changes: The discourse of change emerged mainly round the collocate zména, zménit '(to) change'. Motherhood means a change, it has a potential to change women: V čem Vás mateřství změnilo? ('What has motherhood changed in you?')

Activity: Motherhood is active; activity was discussed in relation to the Movement for Active Motherhood, the aim of which was to make conditions for delivering women better, giving them voice to implement their own needs and wishes when raising a child. The discourse of activity was concentrated mainly round the collocates aktivní 'active' and hnutí 'movement': Před jedenácti lety založila Hnutí za aktivni mateřství, aby se zlepšily podmínky ve zdejších porodnicích. ('She established the Movement for Active Motherhood to improve conditions in local maternity hospitals.')

Time: Time factors play an important role in motherhood; the discourse of time emerged mainly round the collocates doba 'period', pozdni 'late', rok 'year', ted' 'now', odsouváni 'postponing', odkládat 'postpone', posledni 'last' and čas 'time'. It referred mostly to postponed motherhood - odsouváni mateřství na pozdějši dobu 'postponing motherhood to a later age'; Patřite k ženám, které mateřství odkládaly kvili kariére? ('Are you among women who postpone motherhood for career?') or to recent changes - Pozdni mateřství je in. Poslední dobou si potomky "na stará kolena" pořizuje stále vice celebrit. ('Late motherhood is in. In recent years, celebrities have been having offspring at a later age.'); Ted' je kult mateřství jiný a často až extrémní. ('Nowadays, the cult of motherhood is different, often even extreme.') Late motherhood brings benefits (woman's maturity) as well as risks nebezpeči neplodnosti 'threat of infertility'.

\section{SUMMARY}

In order to survey what leading issues related to motherhood Czech journalistic texts present and what discourse of motherhood they produce, we decided to analyze the lemma materstvi 'motherhood' in them. We applied the CADS approach in compliance with Baker and commented on the frequency of the lemma with regard to a medium, journal title, text type and genre; we made its collocation analysis on the basis of the T-score association measure, and classified the collocates into discourse categories. Afterwards, we searched for repeated discourse patterns that the lemma appeared in by means of a concordance analysis. 
We found out that the lemma was more frequent in magazines than in newspapers, most common in the genre of lifestyle, social life and society, and in terms of magazines, it occurred mostly in women's magazines. The chief discourseof-motherhood categories were: surrogate motherhood, relationship between motherhood and career, delight from motherhood, family relationships, financial and time aspects of motherhood, changes due to motherhood, and active motherhood. Surrogate motherhood was presented as a solution for women who cannot have a baby themselves, nevertheless also as a complicated issue due to the unclear status of the biological and "target" mother; emphasis was put on relevant legislation. Motherhood was further presented as a danger for a woman's career, as a result of which women were forced to make a pro-motherhood / pro-career choice, postpone motherhood to later life periods, or somehow try to balance both. Mothers experience discrimination in the labor market as it is mostly them who bear the burden of childcare. On the other hand, motherhood was perceived also as a source of joy, an essential relationship in a family, as a right to financial support, as a change in a woman's life, as an activity, and as an entity closely connected to time factors.

Being aware of research limits and challenges, e.g. lack of possibility to compare the discourse of individual titles, need for data from older corpora, need for analyzing lemmas corresponding with motherhood, and need for analyzing spoken language, we are going to treat them in our further research.

\section{ACKNOWLEDGMENTS}

This study was supported by grant No. SGS02/FF/2019.

\section{References}

[1] Baker, P. (2006). Using Corpora in Discourse Analysis. London, Continuum.

[2] Baker, P., Gabrielatos, C., Khosravinik, M., Krzyzanowski, M., McEnery, T., and Wodak, R. (2008). A Useful Methodological Synergy? Combining Critical Discourse Analysis and Corpus Linguistics to Examine Discourses of Refugees and Asylum Seekers in the UK Press. Discourse and Society, 19(3), pages 273-306.

[3] Křen, M., Cvrček, V. et al. (2016). SYN2015: Representative Corpus of Contemporary Written Czech. In Proceedings of the Tenth International Conference on Language Resources and Evaluation (LREC'16), pages 2522-2528, Portorož. ELRA.

[4] Kubát, M., Hůla, J. et al. (2018). The Lexical Context in a Style Analysis: A Word Embeddings Approach. Corpus Linguistics and Linguistic Theory. Accessible at: https : / / www. degruyter.com/view/j/cllt.ahead-of-print/cllt-2018-0003/ cllt-2018-0003.xml.

[5] Stubbs, M. (1983). Discourse Analysis: The Sociolinguistic Analysis of Natural Language. Chicago, IL: The University of Chicago Press. 
[6] Fairclough, N. (2004). Analysing Discourse. Textual Analysis for Social Research. New York, London, Routledge.

[7] Blommaert, J. (2005). Discourse: A Critical Introduction. Cambridge, Cambridge University Press.

[8] Buchanan, L. (2013). Rhetorics of Motherhood. Carbondale, Southern Illinois University Press.

[9] Rich, A. C., and McClatchy, J. D. (2013). Adrienne Rich. Columbia, University of Missouri.

[10] Vincent, C. (2010). The Sociology of Mothering. In The Routledge International Handbook of the Sociology of Education, pages 109-120, New York, London, Routledge.

[11] Haratyan, F. (2012). Contradictory Discourses of Motherhood as Institution and Experience. Southeast Asian Review of English, 51(1), pages 40-47.

[12] Butler, J. (2010). Performative Agency. Journal of Economy, 3 (2), pages 147-161.

[13] Parker, R. (1997). The Production and Purposes of Maternal Ambivalence. In Mothering and Ambivalence, pages 17-36, Blackwell, Psychology Press.

[14] Woodward, K. (1994). Discourses of Motherhood in Women's Magazines in Contemporary Britain. Doctoral thesis. Sheffield Hallam University.

[15] Tomešová, K. (2008). Mediální obraz těhotenství ve vybraných časopisech pro rodinu [Media Discourse of Pregnancy in Chosen Family Magazines]. Bachelor work. Brno, MU Brno.

[16] Brezina, V. (2018). Statistics in Corpus Linguistics. A Practical Guide. Cambridge, Cambridge University Press. 